\title{
Development of News Text Teaching Materials for Junior High Schools Based on Journalistic Studies
}

\author{
Arip Samsul Aripin 1, ", Suherli Kusmana ${ }^{1, ~ *, ~ D e d e ~ E n d a n g ~ M a s c i t a ~}{ }^{2}$ \\ ${ }^{1}$ Postgraduate School, Swadaya Gunung Jati University, Cirebon, Indonesia \\ ${ }^{2}$ Teacher Training and Education Faculty, Swadaya Gunung Jati University, Cirebon, Indonesia
}

\section{Email address:}

aripsamsul1991@gmail.com (A. S. Aripin)

${ }^{*}$ Corresponding author

\section{To cite this article:}

Arip Samsul Aripin, Suherli Kusmana, Dede Endang Mascita. Development of News Text Teaching Materials for Junior High Schools Based on Journalistic Studies. International Journal of Secondary Education. Vol. 9, No. 1, 2021, pp. 10-16. doi: 10.11648/j.ijsedu.20210901.12

Received: December 22, 2020; Accepted: January 8, 2021; Published: January 22, 2021

\begin{abstract}
The purpose of this study was to obtain news text teaching materials based on journalism and discourse studies for junior high school students. The object of this research is the selected critical discourse news texts. The method used is the method of research and development. The study begins with a descriptive analysis of the news text based on a journalistic study, namely the structure, shape, and feasibility elements. Meanwhile, the discourse study includes critical discourse analysis. From this study, news text teaching materials for junior high schools were developed through validation and due diligence. The results of this research are news text structures based on journalism and discourse which are used as the basis for developing news text teaching materials for learning. News text teaching materials can be developed into enrichment teaching materials and based on the validation test of Indonesian language teachers and experts, the teaching materials can be categorized as valid and suitable for use in learning. The results of this study are: the structure of the news text under study is based on journalism. Of the ten news texts, only two are news texts in the form of features with the headline The Success Story of Hijup Diajeng Lestari Founder and the Early Story of Mendikbud Nadiem Makarim in Founding GoJek. The other eight texts are in the form of a quote story. Meanwhile, news texts based on the results of research on discourse do not find any elements of marginalization, so that the mass media can be said to be balanced and independent from the press court. Furthermore, the study of teaching materials for student knowledge enrichment books that were made and tested by the validation of teaching material experts and practitioners based on their judgments was categorized as valid and could be used as an enrichment book for lessons.
\end{abstract}

Keywords: News Text Teaching Materials, Journalism, Discourse

\section{Introduction}

Students' critical reasoning skills need to be activated through learning to deal with the flood of information or news in the digital era. News can be used as access to information to build a person rich in references and arguments instead of becoming a person who is poor in literacy and has sentiment.

Fake news or hoaxes have shocked the Indonesian nation along with the development of smartphones designed for ease of use and to meet all human needs in socializing, economics, and meeting information needs. The state is even very worried about hoaxes. The Ministry of Information said that there are around 800,000 websites spreading fake news in Indonesia. Facts on the ground are indeed many victims of hoaxes due to the readers' lack of critical reasoning. Not only the general public, but even intellectuals can be hit by hoax news.

Based on the research, it is known that in general journalists or mass media editors will write according to their taste or according to people who have an interest in constructing discourse through the news. Therefore, in learning news texts students need to be equipped with understanding, not only questioning curls, elements, and structure and writing news texts, but the spirit of the news is made and all the consequences need to be understood.

The number of important events in the student's residence 
can be used as learning in life. The rapid advancement of the internet as a messenger of information or news as well as very easy access in spreading information cannot be limited and is difficult for teachers to control. News can be a source of inspiration and can also be a source of disaster, because every news contains a message and aims to influence society. Therefore, students must be equipped with teaching materials that provide a broad understanding of news texts as part of journalism and discourse science.

Based on this, it is necessary to develop news text teaching materials from the results of news text studies based on journalism and discourse science. This teaching material can also be used as a book to enrich student knowledge about news texts for students in learning.

\section{Literature Review}

\subsection{News Text}

News is information that contains an unusual event based on the fact or opinion of someone who is important for the public to know with his distinctive style of writing from the most important to the less important. The definition of news according to experts, "News is actual information about facts and opinions that attract people's attention". [12]. Another expert stated that news is: information reports that attract the attention of the consumer community, based on, in the form of events and / or ideas (opinions), arranged in such a way and disseminated by the mass media as soon as possible [14]. Charley stated that news as the fastest report of an event or actual incident, is important and interesting to readers and touch their interests [4].

News text has a building block, namely: what, where, when, who, why, and how or what is better known as ADIKSIMBA or the $5 \mathrm{~W}+1 \mathrm{H}$ formula. As for the form of news text, according to Ishwara, news is divided into two types, namely event-centered news and process-centered news. (1) Event-centered news presents hot events. which have just happened, and are generally not interpreted, with a minimal context, are not connected to other situations and events. (2) News based on the process presented with an interpretation of conditions and situations in society that are connected to a broad context and beyond time This kind of news appears on special pages such as editorials, features and special reports [8].

The news text also has a structure. According to the author, the structure of the news is the building block of a news text with the building, title, lead, and body of the news. Like prose, fiction also contains a building structure. Kusumaningrat and Kusumaningrat distinguish between fiction and news. He stated that a novel or drama, in general, begins its story with a story setting or the background of the story's course, then develops towards the climax. However, it is not the case with news, it uses the opposite structure [12].

The terms for the structure of the news text Suranto and Lopulalan call it the anatomy of news. News anatomy is the part that makes up a story. The anatomy of the news consists of three parts, namely: the headline, the lead, and the body [17].

News is related to many people, so as public consumption, news needs corridors or rules, that the news is suitable for public consumption. In fact, that the press is the fourth pillar of democracy after the executive, legislative and judiciary, therefore journals work for the community, not for the rulers or just looking for profit on news.

The element of news feasibility there are five special characteristics of news that build working principles and determine the forms of news practice that serve as guidelines in presenting and assessing the appropriateness of a news, the elements are as follows: (1) News must be accurate, News must be complete, fair and balanced; (2) News must be objective; (3) News must be concise and clear; (3) The news must be warm [12].

The value of news is anything that becomes a factor whether it is valuable to be made into news and the public is interested in what is reported about an incident by the mass media. Therefore there are elements that build a news value. According to Mondry, the elements of a news value are arranged as follows. (1) (Immediacy / timelines; (2) Proximity; (3) Consequence; (4) Conflict; (5) oddity / extraordinary; (6) Sex; (7) Emotion; (8) Prominence; (9) Suspense; (10) Progress. [14].

News is the result of the description or conceptualization of an event or factual incident constructed into a desired reality. All media content is a reality that has been constructed in a meaningful form [1]. Nevertheless the meaningfulness is the result of the reconstruction process from the previous objective reality.

\subsection{Journalism and Reading}

The main concept of Critical Discourse Analysis (CDA) is not merely analyzing to find a description of the use of language in a discourse, but CDA is oriented to dismantle the practice of power in constructing discourse in marginalizing certain groups. Eriyanto explained that individuals are not considered as neutral subjects who can interpret freely according to their thoughts, because they are closely related and influenced by social forces in society. Language here is not understood as a neutral medium that lies outside the reader [6]. Meanwhile, according to Darma, the basic understanding of CDA is not understood solely as an object of language study. Language is not seen in the traditional linguistic sense. Language in critical discourse analysis in addition to text is also in the context of language as a tool used for certain purposes and practices including ideological practice [2]. Idiological practice is shown in the same way that the editor of Social Texs magazine has passed Alan Sokal's hoax essay because the editor considers Alan Sokal's writing in accordance with their postmodern ideology.

Darma Suggests that in discourse assessment, at least there are several things that should be reviewed. These include, among others, social actors, time, distance, conditions, presentation style, location including construction legitimation, construction objectives, and visual 
representations of social action [2]. Darma stated that Theo van Leeuwen's model of critical discourse analysis in general displays how parties and actors (can be a person or a group) are presented in the news [2].

Answering how actors are presented in the media there are two processes the actors are presented. First is the exclusion process and the second is the inclusion process. The two processes Eriyanto explained, first was the process of exclusion, whether in a news text, there was a group or actor that was released in the news, and what discourse strategy was used for that. This expenditure process can change the audience's understanding of an issue and legitimize a certain position of understanding. The second is the inclusion process. Inclusion relates to the question of how each party or group is presented through reporting [6].

\subsection{Teaching Materials}

Teaching materials are all sources of knowledge, both written and unwritten, which can be used as teaching material by the facilitator / teacher in classroom learning activities. According to Khaerudin, Kusmana and Robia, to support a quality and meaningful learning process, teaching materials are needed [18]. Teaching materials can be understood in broad terms as also explained by Khaerudin, Kusmana and Robia, which consist of knowledge, skills, and attitudes that must be learned to achieve student competency standards [18].

Teaching materials are divided into several groups or types of teaching materials, as explained by the Ministry of National Education that teaching materials can be grouped into four categories, namely printed materials such as handouts, books, modules, student worksheets, brochures, leaflets. Hearing teaching materials such as cassettes, radios, LPs, and audio compact disks. Visual teaching materials such as video compact disks, films. Interactive multimedia teaching materials such as CAI (Computer Assisted Instruction), multimedia interactive learning compact disks (CDs), and web-based teaching materials [3].

There is also a research that concentrates on printed teaching materials. Printed teaching materials can be interpreted as a source of knowledge that can be used as teaching material by the facilitator / teacher in classroom learning activities in the form of writing printed on a paper.

According to Khoiru, printed teaching materials can be interpreted as a source of knowledge that can be used as teaching material by the facilitator / teacher in classroom learning activities in the form of writing printed on a paper. Khoiru defines that teaching materials are all forms of materials used to assist teachers / instructors in carrying out teaching and learning activities in the classroom [11].

The development of printed teaching materials in question is the making of lesson enrichment books on news texts based on the needs of students and teachers in order to achieve learning competency standards. The product of this enrichment book is tested for validation by teaching material experts and practitioners (Indonesian language subject teachers). Furthermore, the results of the validation were revised according to the assessment of experts and practitioners. After the product is revised, it can be used by students to support learning news texts according to the Basic Competencies (BC) that students must meet.

The enrichment books made are included in the nontextbook type. The meaning of a non-text book cannot be separated from the meaning of the book itself. In the Oxford dictionary, a book is defined as the number of sheets of paper, either printed or blank, fastened together in a cover, which means a number of sheets of paper, both printed and blank, which are bound and covered with skin. Bigi also according to KBBI a book is defined as sheets of paper which are bound, contain writing or are blank.

Enrichment books are a part of the non-textbook type. Judging from the name, it is clear that enrichment books serve to enrich the reader's insight, experience and knowledge. The Center for Book of the Ministry of National Education (Pusat Perbukuan Departemen Pendidikan Nasional) defines enrichment books as enrichment books in this guideline which means books containing material that can enrich and improve mastery of science and technology and skills; shape the personalities of students, educators, education managers, and other reading societies. Enrichment books can be grouped into three groups, namely knowledge enrichment books, skills enrichment books, and personality enrichment books [10].

The definition of enrichment books at the Center for Curriculum and Books of the Ministry of Education and Culture emphasizes this enrichment book for students who have three functions, namely: (a) increasing knowledge insight; (b) improve skills; (c) improve the personality of students. Therefore in research the development of this teaching material is included in the function of increasing knowledge insight.

According to Kusmana, non-text textbooks are books that are not used directly as books to study a field of study in educational institutions [19]. Kusmana also explained that non-text books are books that contain supporting material with loose, creative, and innovative presentations and can be used by general readers [19]. Even so, in the development of teaching materials made by this researcher, it emphasizes the fulfillment of the student learning process to achieve Basic Competencies (BC).

\section{Method}

The research method used is descriptive qualitative method. According to Heryadi, descriptive research is research that intends to describe situations or incidents of a subject that contain phenomena [7]. This descriptive method is used to analyze news text based on journalism which includes the elements, form, and feasibility of the news text. There are also steps, namely: (a) reading the news text carefully; (b) analyzing one by one the news texts based on their elements, form and value of feasibility; (c) conclude the results of the analysis work. Likewise, to examine news texts based on critical discourse analysis using a descriptive analysis method with the following steps: (a) reading the 
news text carefully; (b) analyze the news texts one by one based on the strategy of exclusion and inclusion; (c) conclude the results of the analysis work.

In addition to the qualitative descriptive method, this study also uses research and development methods (resech and development). Research and Development ( $\mathrm{R}$ and $\mathrm{D})$ is a research method used to produce certain products, and to test the effectiveness of these products [16]. The concept of $\mathrm{R}$ and $\mathrm{D}$ starts from the needs analysis and then requires the manufacture of products, so the effectiveness of these products needs to be examined to meet needs. This research and development carries out continuous product improvements or revisions in order to create products that suit your needs.

For research and development of teaching materials, this research procedure adapts the ADDIE development model which consists of five stages including analysis, design, development, implementation and evaluation [15]. There are also steps taken in this method, namely: (1) Basic Competency analysis class VIII curriculum 2013; (2) making enrichment books; (3) validating teaching material experts and practitioners as well as making product revisions; (4) product use; (5) assessment of the effectiveness of enrichment books in meeting student learning needs.

Sources of data in this study are printed and online news texts, BC class VIII curriculum 2013, validation results from teaching material experts and practitioners or Indonesian language subject teachers to the enrichment books made.

\section{Results and Discussion}

\subsection{Research Result}

The analysis of the structure of the news text above can be concluded that in the analysis of the structure of the news text there are indicators 1) the title reflects the content of the news text, 2) the ideal lead does not exceed 45 words and 3) the news body contains explanations or supporting facts of the news. Of the 10 headlines analyzed, all of them met all indicators.

There are also news text headlines that meet the indicators below, namely: (1) Proposal for PDAU to be Disbanded, the Restoration Faction-PDIP Assuming Never Contributed; (2) PAD PDAU is only Rp. 4.6 million, before it is dissolved, DPRD should give a check and time to change; (3) Better to Manage Disporapar, Darma Reservoir Revenue Expires by Employee Spending at PDAU; (4) Acep Affirms There Will Be Eradication in PDAU; (5) PDAU Must Be Saved, Be Thrifty, Vice Regent Suggests Management of PDAU Restructured; (6) PKB Chair: Better to Disband PDAU; (7) PDAU Is Still Living Priest: Since 2017 Has Never Received Equity Participation Budget; (8) Success Story of Hijup Diajeng Lestari Founder; (9) Journalist Profession Leads Bamsoet to Become a Successful Politician; (10) Early Story of the Minister of Education and Culture Nadiem Makarim in establishing GoJek.

The results of the analysis of the form of news texts on 10 news texts, namely 8 news texts in the form of quote stories with the following characteristics: (1) quite important; (2) originating from events and / or statements from one, two or more sources; (3) if it is described as an inverted pyramid which is constructed by: title, lead, body of news (transitions and quotes). Meanwhile, 2 news texts are in the form of features, with the title Success Story of the Founder of Hijup Diajeng Lestari and the Early Story of the Minister of Education and Culture, Nadiem Makarim, in establishing GoJek. There are also characteristics, namely: (1) Attractive; (2) Intended to entertain, surprise, amused, amazed, anxious, touched, pity, annoyed, educate, increase knowledge, create a sense of beauty (writing emphasizes the touch of emotion).

\subsection{Feasibility Element Analysis of News Text}

The results of the analysis of the elements of the feasibility of the news text above with the 5 points (1) accuracy; (2) complete, fair and balanced; (3) objective; (4) concise and clear and (5) warm, it can be concluded that from the 10 news texts analyzed, all of them meet the news feasibility element.

\subsection{Analysis of News Texts Based on Discourse}

The results of the analysis of news texts in a discourse, of the 10 news texts analyzed, the researcher did not find any elements of marginalization in the news texts which were analyzed either through the level of expenditure or the level of income of van Lueewen's Theo theory.

\subsection{Analysis of Teaching Materials Based on the Psychological Aspects of Students}

Based on the criteria for selecting news texts as teaching materials, in the psychological development aspects of students, the number of conformity indicators obtained is 12 indicators. Based on the assessment of the suitability of the news text on the criteria for selecting teaching materials, it refers to the stages of development of behavior and personality (student psychology) that the news text with the title: (1) Success Story of Hijup Diajeng Lestari Founder; (2) Journalist Profession Leads Bamsoet to Become a Successful Politician, (3) The Story of Mendikbud Nadiem Makarim's Beginning in Establishing GoJek. The three news texts with the title are categorized as good teaching materials and in accordance with children's psychological development.

\subsection{Feasibility Analysis of the Development of Enrichment Book Teaching Materials}

The eligibility criteria for teaching materials for enriching knowledge about news texts are as follows.

Table 1. Validation of Enrichment Book Teaching Materials.

\begin{tabular}{lll}
\hline Percentage (\%) & Validation Level & Information \\
\hline $80-100$ & Valid & No Revision \\
$60-79$ & Enough Valid & No Revision \\
$40-59$ & Less Valid & Partial Revision \\
$0-39$ & No Valid & Total Revisions \\
\hline
\end{tabular}




\subsection{Data Analysis of Expert Lecturer Validation Results}

The results of the assessment given by the expert lecturer showed that the enrichment book made by the researcher was declared valid enough as evidenced by the following results: (1) the material supports the achievement of national education goals, with a percentage value of $79 \%$ This shows quite valid; (2) the material does not contradict the ideology and political policies of the state, with a percentage value of $100 \%$. This indicates valid; (3) material on avoiding racial issues, gender bias, and human rights violations, with a percentage value of $100 \%$. This indicates valid; (4) the material written is in accordance with the latest scientific developments, valid, and accurate, with a percentage value of $79 \%$. This shows quite valid; (5) optimizing the use of sources in accordance with the conditions in Indonesia, with a percentage value of $79 \%$. This shows quite valid; (6) the material or book content develops academic, social, and vocational skills to solve problems, with a percentage value of $59 \%$. This indicates less validity; (7) the material or content of the book has maximally developed the desirable personality characteristics of the Indonesian people and a solid personality, with a percentage value of $59 \%$. This indicates less validity; (8) books pay attention to the development of academic skills, creativity, ability to innovate, with a percentage value of $59 \%$. This indicates less validity; (9) easy to do, familiar (intimate with readers), and fun, with a percentage score of $79 \%$. This shows quite valid; (10) can stimulate the development of creativity, and stimulate readers to apply based on work stages, with a percentage value of 59\%. This indicates less validity; (11) illustrations (pictures, photos, diagrams, tables, symbols, legends) in the book, the use is appropriate and proportional, with a percentage value of $59 \%$. This indicates less validity; (12) in using the term or symbol it is standardized and applies as a whole, with a percentage value of $59 \%$. This indicates less validity; (13) in using language, which includes spelling, words, sentences, and paragraphs that are correct, straightforward and clear, with a percentage value of $79 \%$. This shows quite valid; (14) the books were bound neatly and strongly, with a percentage value of $39 \%$. This indicates invalid; (15) books use legible letters and / or pictures / illustrations, with a percentage value of $59 \%$. This indicates less validity; (16) books are printed clearly and neatly, with a percentage value of $59 \%$. This indicates less validity; (17) books use quality and safe paper, with a percentage value of $59 \%$. This indicates less validity.

The overall value of the questionnaire assessment is explained as follows.

$$
\mathrm{P}=\frac{\sum \times}{\sum \times \mathrm{i}} \times 100 \%=\frac{42}{68} \times 100 \%=61.7 \%
$$

Information:

P: Percentage sought.

$\Sigma \times$ : Total score of validator answers (real value).

$\Sigma \times$ i: Total amount of the highest score (expected value).
The results of the validation of expert lecturers teaching materials for news text enrichment books reached $61.7 \%$, which is quite valid and does not need to be further revised. However, for the sake of improving the book, the writer of the revision received suggestions from expert lecturers so that the enrichment book could be declared suitable for use.

\section{Discussion}

\subsection{Previous Research}

A similar previous research regarding the development of teaching materials was conducted by Suharsono Degita Danur with the title of research on the Development of Teaching Materials for Feature Writing Based on the Results of the Analysis of Learning Needs of Journalism Program Students at State University of Malang [20]. This research is aimed at developing teaching materials for writing features for journalism students using development research methods. This development research begins with a preliminary study which is focused on analyzing the needs of students and lecturers in feature learning. The next step is mapping the learning domain including learning objectives, learning materials, and exercises. The results of the learning needs analysis are used as a reference for the next stage, namely the development of teaching materials.

Similar research on news technology was also conducted by Dwijayanthi, Sutama, and Wisudariani with the research title Analysis of News Writing Teaching Materials for Class VIII of SMP Negeri 3 Banjar [20]. The research aims (1) to describe the suitability of writing news teaching materials with learning planning tools in class VIII SMP Negeri 3 Banjar, (2) to find out students' responses to the use of news writing teaching materials compiled by Indonesian language teachers at SMP Negeri 3 Banjar in class VIII SMP Negeri 3 Banjar, (3) knows the constraints of teachers when using teaching materials to write news in class VIII of SMP Negeri 3 Banjar. This research used qualitative descriptive research.

From previous research on news text research, there has never been a research that combines descriptive analysis research and development research. Research on the development of teaching materials, especially non-text teaching materials about news texts, requires prior research on news texts based on journalistic science and critical discourse analysis science as a barometer of the news text whether students should study it. Meanwhile, the research and development is an effort to facilitate students in learning the news text material.

The teaching material developed in this study is the creation of a textbook enrichment lesson with news texts which the author entitled Knowledge and News Writing Techniques. This lesson enrichment book was written to meet the elements of Basic Ccompetencies class VIII. There are also the results of the validation of Indonesian language teachers (practitioners) which can be explained as follows. 


\subsection{Data Analysis of Indonesian Language Teacher Validation Results}

The results of the assessment given by the Indonesian Language Teacher stated that the enrichment book made by the researcher was declared valid, as evidenced by the following results: (a) the material supports the achievement of national education goals, with a percentage value of $91 \%$. This indicates that it is valid; (b) the material does not contradict the ideology and political policies of the state, with a percentage value of $94.6 \%$. This indicates that it is valid; (c) material on avoiding racial issues, gender bias, and human rights violations, with a percentage value of $94.6 \%$. This indicates that it is valid; (d) written material in accordance with the latest scientific developments, valid, and accurate, with a percentage value of $85.7 \%$. This indicates that it is valid; (e) optimizing the use of sources in accordance with the conditions in Indonesia, with a percentage value of $83.9 \%$. This indicates that it is valid; (f) the material or book content develops academic, social, and honesty (vocational) skills to solve problems, with a percentage value of $82.1 \%$. This indicates that it is valid; $(\mathrm{g})$ the material or contents of the book have maximally developed the desirable personality characteristics of the Indonesian people and a solid personality, with a percentage value of $76.7 \%$. This indicates that it is valid; (h) the book pays attention to the development of academic skills, creativity, the ability to innovate, with a percentage value of $80.3 \%$. This indicates that it is valid; (i) easy to do, familiar (intimate with readers), and fun, with a percentage score of $69.6 \%$. This indicates that it is valid; (j) can stimulate the development of creativity, and stimulate readers to apply based on work stages, with a percentage value of $78.5 \%$. This indicates that it is valid; $(\mathrm{k})$ illustrations (pictures, photos, diagrams, tables, symbols, legends) in the book, the use is appropriate and proportional, with a percentage value of $71.4 \%$. This indicates that it is valid; $(\mathrm{m})$ in using the term or symbol it is standardized and applies as a whole, with a percentage value of $80.3 \%$. This indicates that it is valid; (n) in using language, which includes spelling, words, sentences, and paragraphs that are correct, straightforward, and clear, with a percentage value of $76.7 \%$. This indicates that it is valid; (o) the books are bound neatly and strongly, with a percentage value of $76.7 \%$. This indicates that it is valid; (p) the book uses legible letters and / or pictures / illustrations, with a percentage value of $82.1 \%$. This indicates that it is valid; (q) the book is printed clearly and neatly, with a percentage value of $80.3 \%$. This indicates that it is valid; (r) the book uses quality and safe paper, with a percentage value of $76.7 \%$. This shows that it is valid.

The overall value of the questionnaire assessment is explained as follows.

$$
\mathrm{P}=\frac{\Sigma \times}{\sum \times \mathrm{i}} \times 100 \%=\frac{772}{952} \times 100 \%=81 \%
$$

Information:

P: Percentage sought.
$\Sigma \times$ : Total score of validator answers (real value).

$\Sigma \times$ i: Total amount of the highest score (expected value).

The results of the validation of Indonesian language teachers at SMP / MTs teaching materials for news text enrichment books reached $81 \%$ in the valid criteria and did not need to be further revised. The enrichment book is worth using.

\section{Conclusion}

Based on the research conducted, it can be concluded as follows:

1. The structure of the news text based on journalism (structure, form, and feasibility) is assessed as a whole to fulfill journalistic elements. As for the form, out of 10 news texts only 2 news texts are in the form of features with the headline The Success Story of Hijup Diajeng Lestari Founder, Story and the Beginning of the Minister of Education and Culture Nadiem Makarim Founding GoJek. The other eight texts are in the form of a quote story.

2. The text of the results of research based on discourse does not have an element of marginalizing a particular group or social actor, so that the mass media can be declared balanced (cover both side) and separated from the press court (trial by the pres).

3. News text teaching materials in the form of lesson enrichment books for SMP / MTs students that use news texts as teaching materials based on the validation test of teaching material experts (expert lecturers) and Indonesian language teachers (practitioners) spread across SMP Negeri 1 and 2 Kuningan, SMP Itus and Binaul Ummah Kuningan, MTs Negeri 3 and 7 Kuningan as well as MTs PUI Ciawigebang each have two Indonesian language teachers who have taught at least 5 years, based on their judgments an average of $81 \%$ are categorized as valid and usable; (d) The product of the enrichment book compiled by the researcher consists of 6 CHAPTERS. CHAPTER I contains news and terminology to the role and function of the press, CHAPTER II News Text, CHAPTER II regarding News Text Structure, CHAPTER IV News Appropriateness and Value, CHAPTER V regarding News Text Language, CHAPTER VI Regarding News Text Writing Techniques In CHAPTER II this book can answer the needs of SMP / MTs class VIII students at BC 3.1 Identifying the elements of the news text (boasting and motivating) as well as answering indirectly BC 4.1 Concluding the content of the news (boasting and motivating). In CHAPTER III and CHAPTER V can answer the needs of BC 3.2 Examine the structure and language of the news text (boast and motivate). Furthermore, CHAPTER VI of this book can answer BC 4.1 Presenting data and information in the form of written news.

4. Based on the feasibility test, the teaching materials or enrichment books for class VIII SMP / MTs students 
which are entitled Knowledge and News Writing Techniques are declared valid and can be used by class VIII SMP / MTs students.

\section{References}

[1] Badara, A. (2012). Analisis Wacana Teori, Metode, dan Penerapannya pada Wacana Media. Jakarta: Kencana Prenada Kencana Grup.

[2] Darma, Y. A. (2014). Analisis Wacana Kritis, dalam Multiperspektif. Bandung: Refika Aditama.

[3] Depdiknas. (2008). Panduan Pengembangan Bahan Ajar. Departemen Pendidikan Nasional.

[4] Dwijayanthi, Sutama, \& Wisudariani. (2015). Analisis Bahan Ajar Menulis Berita Kelas VIII SMP Negeri 3 Banjar. eJournal JJPBS Universitas Pendidikan Ganesa, 3.

[5] Effendi, A. S. (2005). Kebebasan Pers dan Kode Etik Jurnalistik. Yogyakarta: UII PRESS.

[6] Eriyanto. (2011). Analisis Wacana, Pengantar analisis Teks Media. Yogyakarta: LKis Printing Cemerlang.

[7] Heryadi, D. (2010). Metode Penelitian Pendidikan Bahasa. Bandung: Pusbill.

[8] Ishwara, L. (2011). Jurnalisme Dasar. Jakarta: Kompas Media Nusantara.

[9] KBBI. (2008). Kamus Besar Bahasa Indonesia Edisi Ke Empat. Jakarta : Gramedia Pustaka Utama.

[10] Kebudayaan, K. P. (2018). Panduan Pemilihan Buku Nonteks
Pelajaran. Jakarta: Pusat Kurikulum dan Perbukuan, Balitbang, Kemendikbud.

[11] Khoiru, A. I. (2011). Strategi Pembelajaran Sekolah Terpadu. Jakarta: Prestasi Pustaka.

[12] Kusumaningrat, H., \& Kusumaningrat, P. (2017). Jurnalistik Teori \& Praktik. Bandung: Remaja Rosdakarya.

[13] McQuail, D. (2011). Teori Komunikasi Massa, Suatu Pengantar. Jakarta: Erlangga.

[14] Mondry. (2008). Pemahaman Teori dan Praktik Jurnalistik. Bogor: Ghalia Indonesia.

[15] Sugiyono. (2015). Metode Penelitian dan Pengembangan. Bandung: Alfabeta.

[16] Sugiyono. (2017). Metode Penelitian Pendidikan (Pendekatan Kuantitatif, Kualitatif, dan R \& D). Bandung: Alfabeta.

[17] Suranto, H., \& Lopulalan, D. (2000). Menjadi Wartawan Lokal. Jakarta: Lembaga Studi Pers dan Pembangunan.

[18] Khaerudin, D., Kusmana, S., \& Khaerudin, I. R. (2019). Pengembangan Bahan Ajar Pengalaman Pengarang Sebagai Bahan Ajar Drama di SMP/MTs. www.download.garuda.resteBCikti.go.id. (Accessed 1 Decsember 2020).

[19] Kusmana, S. (2008, 30 Agustus). Mengenal Buku Nonteks Pelajaran (Part I). Accessed 23 September 2020, from www.suherlicentre.blogspot.com.

[20] Suharsono, D. D. (2020). Pengembangan Bahan Ajar Menulis Feature Berdasarkan Hasil Analisis Kebutuhan Belajar Mahasiswa Program Jurnalistik di Universitas Negeri Malang. Jurnal Kiprah, 8, 27-37. 